\title{
Linguistic innovation during the COVID-19 pandemic: the Spanish language case
}

\author{
Anna Zholobova
}

DOI: $10.18355 /$ XL.2021.14.02.24

\begin{abstract}
The paper contributes to the study of the impact that the COVID-19 pandemic has produced and is producing at the present moment on the Spanish language. The impact is, of course, reflected at the lexical level as many new words and expressions have been coined to designate segments of new extralinguistic reality generated by the pandemic and the "new normal". The article analyses recent "pandemic" updates of the Spanish Royal Academy dictionary electronic version DLE 23.4 and "covidic" neologisms and occasionalisms from semantical and morphological points of view.

Key words: Spanish language, neology, word-formation, occasionalisms, COVID-19 pandemic
\end{abstract}

\section{Introduction}

Our life and our society are constantly changing, and so is the language, which like a meticulous notary, attests and registers every socially significant change. As is well known, from the lexical point of view, such changes take the shape of neologisms which may either be conserved in the language or disappear with time. One of the most significant impacts on human life was produced, without any doubt, by the coronavirus and the COVID-19 pandemic, which has generated a lot of new concepts and neologisms in languages all over the world.

The pandemic has given birth to numerous new medical and microbiological terms, primarily in the English language as it is the lingua franca of scientific research. For example, COVID-19 and coronavirus are well-known international English loanwords. So, in the Spanish "covidic" terminology there can be found many semantic and formal anglicisms with different grades of adaption. In the terminological sphere it is necessary to mention the English-Spanish on-line COVID-19 glossary Glosario de covid-19 (EN-ES). Its current version (v. 1.16, January 2020) has more than 5100 lemmas in total, most of which refer to virological concepts, molecular concepts, scales, vaccines, diagnostic tests, and medical devices related to COVID-19 (Saladrigas, 2020).

As far as the Spanish language, in general, is concerned, it is worth noting the labor of the Foundation of Urgent Spanish (Fúndeu), which in its website comments on many "covidic" neologisms or terms and gives recommendations of its correct usage (https://www.fundeu.es/recomendacion/coronavirus-claves-de-escritura/; https://fundeu.es/coronavirus-recomendaciones-lenguaje/).

Besides, I must mention quite an interesting study conducted by Rafael Rodriguez-Ponga, in which the author describes a "new covidic language" as a result of the COVID-19 pandemic (Rodriguez-Ponga, 2020). The author elaborated a list of 127 "covidic" language elements in Spanish that encompass the following categories:

- $\quad$ war language elements (e.g., guerra);

- neological anglicisms (e.g., covid);

- $\quad$ popularised scientific terms (e.g., coronavirus);

- $\quad$ popularised judicial terms (e.g., confinamiento);

- $\quad$ semantic neologisms (e.g., test, aforo);

- $\quad$ lexicalized acronyms (e.g., epi, erte);

- neologisms formed by suffixation (e.g., covídico, coronavírico);

XLinguae, Volume 14 Issue 2, April 2021, ISSN 1337-8384, eISSN 2453-711X 
- $\quad$ neologisms formed by composition (e.g., coronacrisis);

- neologisms formed simultaneously by composition and suffixation (e.g., sologripista).

Not all of these 127 elements are neologisms in the strict sense of the word. The author, for example, includes such "old" commonly used words as esencial, calma, residencia, guerra, víctima, epicentro, telemedicina, teleeducación, etc.

As far as war metaphors are concerned, these are so extended and so effective in communication that Lakoff and Johnson start their legendary Metaphors We Live By describing the conceptual metaphor ARGUMENT IS WAR (Lakoff 1980). Regarding the medical sphere, there is nothing new in the usage of war metaphors in reference to severe diseases. So, these are widely used in reference to cancer or AIDS (Sontag 1978, Montgomery, 1991). It is interesting to note that war metaphors were also employed, for example, in China and Taiwan in relation with SARS (severe acute respiratory syndrome), an extremely severe disease caused by a coronavirus that emerged in China in 2002. (Chiang, 2007). Isn't $t$ it a sinister déjà vu as COVID-19 is SARS' nearest relative? Curiously, in the British press, the metaphors of war and plague which "have played a very prominent part in framing other epidemics had marginal roles during SARS" (Wallis, 2005: 2632) mainly because there was no real danger for the UK, whereas Taiwanese newspapers described the spread of SARS as "an invasion from China, doubly reinforcing the invasion imagery: Taiwan was being invaded by both the disease and by China" (Chiang 2007: 592). It's quite logical that "war metaphors are used more prominently when the relationship to the disease is 'personal' or perceived as a threat to a "nation"' (Wallis, 2005: 2633). Unfortunately, both things are present in countries all over the world. Besides, war metaphors "evoke a sense of fear", that's why "the war frame is an effective way of grabbing people's attention and focusing it on the target problem" (Flusberg, 2018: 6).

My paper has a different approach and will concern some really new "pandemic" words and meanings. First of all, I'll present a brief theoretical overview of the concepts of neologism, occasionalism, productivity, creativity, and analogy. Secondly, I will focus on the Spanish Royal Academy dictionary "pandemic" updates which were introduced in November of 2020. I will also analyze some other neologisms and occasionalisms derived from or based on what I call key "pandemic" words. And, finally, I'll analyze the corpus of 93 "pandemic" neologisms from different points of view: its part-of-speech characteristics, underlying word-formation processes and from the point of view of creativity and productivity. Almost all examples are taken from the Spanish mass media, the Internet, and the so-called \#Covidcionario (dictionary of COVID-19 neologisms), created in Twitter by Alberto García-Salido and the website https://covidcionario.com/. Some examples are taken from the article of Rodriguez-Ponga (2020). It's important to say that I do not include Latin American material because it needs a specialized study.

\section{The concept of neologism and types of new words}

Neologisms are usually defined as new words, meanings, or expressions, but "newness" is quite a relative and subjective concept. What criteria do we have to follow to classify a word as a neologism? How "old" should it be in order to be considered as one? According to the distinguished Spanish linguist Manuel Alvar, any neologism stops being such as soon as it is registered in a dictionary (Alvar Ezquerra, 2007). Very frequently, linguists follow this lexicographical criterion while selecting corpus for their study, as authentic neologisms don't appear in dictionaries (Diaz Hormigo, 2012). Here I would like to make some observations. On the one hand, language dictionaries can't and shouldn't register absolutely all words and all their possible derivatives and compounds, which may be formed according to regular grammatical procedures (Alvar Ezquerra, 2007). On the other hand, some dictionaries 
may register recently incorporated words perceived as new ones by native speakers. For example, in November of 2020, the Spanish Royal Academy included in its electronic dictionary of the Spanish language (DLE) such words as COVID, COVID19, etc., which, of course, haven't lost their neological character since then. Hence, it seems that the psychological factor is also important. Another factor that should be taken into consideration is a semantic or formal (morphological, graphical or phonetical) instability of neologisms (Cabré, 1993: 445).

As far as types of neologisms are concerned, these are usually classified into two groups:

denominative or referential neologisms;

stylistic neologisms also called occasionalisms or nonce words.

The differences between these two groups may be resumed as follows (Guilbert, 1975, Cabré, 1989 apud Llopart-Saumell 2019):

\begin{tabular}{|l|l|}
\hline Denominative neologism & Stylistic neologism \\
\hline Referential function & Expressive function \\
\hline To communicate the reality & To show the author's personal vision \\
\hline To fit the referent it designates & To draw the attention of the recipient \\
\hline $\begin{array}{l}\text { Use of productive and conventional } \\
\text { forms }\end{array}$ & $\begin{array}{l}\text { Use of non-productive and } \\
\text { unconventional forms }\end{array}$ \\
\hline Considerable frequency of use & Is used to be ephemeral \\
\hline $\begin{array}{l}\text { Corresponds to an objective } \\
\text { necessity }\end{array}$ & Corresponds to a subjective necessity \\
\hline
\end{tabular}

The so-called occasional formations are created to name objects or notions in a witty, original, humorous, more economical, more emphatic, and more expressive way (Estornell Pons, 2013). As a rule, occasional words don't transcend the context they were created for and may completely disappear with time. However, some occasionalisms may gain much popularity and form part of the lexicon of a given linguistic community.

For Honenhaus neologisms are "words that are "young", diachronically speaking, but which nevertheless have already entered the language as more or less institutionalized vocabulary items. As such, they are no longer the output of productive or creative processes but are already given, i.e., listed in the lexicon" (Honenhaus, 2007, 17-18). The linguist uses the term nonce formations as "simply a cover term for all genuinely new formations, whether perfectly regular outputs of productive rules or the result of creative, planned word manufacture" (Honenhaus, 2007: 18). His perception is very close to Matiello's vision: according to her, a neologism is "a new word that is accepted by the speech community and meant to enrich the lexicon"; in contrast, a nonce word or occasionalism is "a new word coined for a particular occasion and not institutionalized" (Matiello, 2017: 25). Nevertheless, both groups "deal with the creation of a new word using the available sources of the language of the community; the difference is merely a matter of whether the speakers pick up the new word" (Bauer 2013).

\section{Productivity, analogy, and creativity}

Speaking about linguistic innovation, we should take into consideration such notions as productivity, creativity, and analogy. It's quite common to distinguish productivity, which is understood as a "rule-governed innovation," and creativity as a "rule-changing" one (Bauer, 1983: 63 apud Lipka 2007: 3). The third notion (analogy) is "the backbone of creativity, i.e., the native speaker's ability to extend the language system in a motivated but unpredictable (non-rule governed) way which may or may

XLinguae, Volume 14 Issue 2, April 2021, ISSN 1337-8384, eISSN 2453-711X 
not subsequently become rule-governed, predictable and productive" (Klegr \& Cermak 2010: 235).

Matiello (2017) demonstrates in her book Analogy in Word-Formation: A Study of English Neologisms and Occasionalisms that analogy is a fundamental principle in word-formation. The linguist distinguishes the following two principal types of analogy:

1. Surface analogy is "the word-formation process whereby a new word (called 'target') is coined that is clearly modeled on a precise actual model word". It differs from rule productivity in that the creation of a new analogical word depends on the similarity with an existing model word, rather than with an abstract pattern, or template, describable in a rule format" (Matiello, 2017: 9). The similarity between the target and the model can be based on the similarity in some traits at different language levels (phonological, morphotactic, semantic);

2. Analogy via schema is the word-formation process whereby a new word is "obtained after a set of concrete prototype words which share the same formation (i.e., series) or some their bases/stems (i.e., word family)"

It is important to indicate that productivity is a gradual concept: thus, we can speak about fully productive, partially productive, and unproductive rules. The concepts of creativity and analogy are also scalar. In this respect, Matiello establishes two hierarchies that demonstrate the relation between analogy and creativity and their gradual character (Matiello 2017, 51):

I. Involves only creativity:

a) Use of unproductive rules (e.g., sloth $\leftarrow$ slow);

b) Violations of a rule (e.g., Shakespearised);

c) More violations of a rule (e.g., James Joyce's endlessnessnessness)

d) No reference to any rule (creations ex nihilo, e.g., gas)

II. Involves creativity and analogy:

a) Use of analogy and productive rule (e.g., battle-worthy after seaworthy);

b) Use of analogy and unproductive rule (e.g., coolth after warmth);

c) Use of analogy without any rule (e.g., half-caf 'a drink of coffee made using caffeinated and decaffeinated coffee mixed in equal parts' is coined after decaf $\leftarrow$ decaffeinated).

\section{New "pandemic" words and meanings in the Spanish Royal Academy's Diccionario de la lengua española (Spanish language dictionary) electronic version DLE 23.4}

In November of 2020, the Spanish Royal Dictionary (RAE) updated the latest edition of its Spanish language dictionary (DLE, 2014) electronic version adding 2557 new entries and amendments. On its official website, the RAE has published a sample of the recently included modifications, among which there are 152 new entries, 54 amendments of meaning, 32 new meanings, and other minor changes (https://dle.rae.es/docs/Novedades_DLE_23.4-Seleccion.pdf). The impact of COVID19 on our life and, thus, on the language was so great that there emerged an urgent necessity to reflect new (and not so new) words and meanings in the Spanish language dictionary, and the RAE had to include the most important COVID-19 pandemic words and meanings in the updated version of its dictionary in the year that the pandemic was declared. We may say that it's something exceptional because, normally, it takes much more time for new words to be registered in the DLE. The new lexicographic entries related with the COVID-19 pandemic are the following: coronavirus, coronavirico, COVID, cuarentenar, cuarentear, encuarentar, desescalada, desconfinar, desconfinamiento, seroprevalencia, videochat, 
videollamada. The entries that have been subject to some modifications are: barbijo, confinar, confinado, confinamiento, cuarentena, mascarilla. Not all the entries have examples of its usage. I will not comment on the word barbijo as it's only used in some Latin American countries.

The following words are labeled in the DLE as medical terms(“Med."):

coronavirus:

m. Med. Virus que produce diversas enfermedades respiratorias en los seres humanos, desde el catarro a la neumonía o la COVID. - "Virus that causes various respiratory diseases in humans, ranging from a cold to pneumonia or COVID."

The RAE indicates that it's an anglicism based on two Latin roots: corona and virus. As is well known, the word itself isn't new: the coronavirus was discovered in the middle of the last century by American scientists who coined the term coronavirus, and it is widely used in specialized language (of medicine or microbiology) (Haddad, 2020), but due to the pandemic it has entered the common language and has become part of our everyday life. As we may appreciate from its definition, the RAE clearly indicates its relation with COVID.

coronavírico, ca "coronaviral" (an adjective derived from coronavirus):

adj. Med. Perteneciente o relativo al coronavirus'. - "Belonging to or relating to the coronavirus".

COVID (maybe used both as a masculine or feminine noun):

m. o f. Med. Síndrome respiratorio agudo producido por un coronavirus "Acute respiratory syndrome caused by a coronavirus". The entry also includes the full name of the disease as its synonym: COVID-19.

Seroprevalencia "seroprevalence":

f. Med. Prevalencia global de un elemento patógeno en la sangre. - "Overall prevalence of a pathogenic element in the blood".

This term is the most technical of the four. The first compositional element sero- stands for 'serum' and may also be found in such words as seropositive "seropositive", seronegative "seronegative", serodiagnóstico "serodiagnostics" and serologia "serology", also registered in the previous edition of the DLE (DLE 2001). The following example can illustrate its usage: "Uno de cada 10 españoles se ha contagiado de Covid 19 según el estudio de seroprevalencia el Instituto de Salud Carlos III" (https://www.elmundo.es/ciencia-y salud/salud/2020/12/15/5fd8d7b4fc6c83dd418b457a.html). - "One in every 10 Spaniards has been infected with COVID-19 according to the seroprevalence study by the Carlos III Health Institute".

\section{Cuarentena word family \\ cuarentena"quarantine"}

7. f. Aislamiento preventivo a que se somete durante un período de tiempo, por razones sanitarias, a personas, animals o cosas. - "Preventive isolation to which persons, animals or things are subjected for a period of time for health reasons".

Cuarentena is a polysemic word and, as a feminine noun, has seven senses according to the DLE (it's lemmatised as cuarenteno, na with nine senses). What was amended is the $7^{\text {th }}$ meaning.

The word itself is quite old: it appears in the first Spanish academic dictionary Diccionario de Autoridades (DA, 1737) within the collocation hacer quarenténa "to be in quarantine" with the following definition: "frase que vale observer cuarenta días, en casa separada, que llaman Lazareto, antes de entrar en el comercio de las gentes, los que se presume vienen de lugares infectos' - "phrase which means to observe those who are presumed to come from infested places in a separate house, called Lazaretto, before they enter people's business during forty días". It may also be found in the bilingual dictionaries of the $17^{\text {th }}-18^{\text {th }}$ centuries (see

XLinguae, Volume 14 Issue 2, April 2021, ISSN 1337-8384, eISSN 2453-711X 
cuarentena or quarentena in NTTLE). Over time the concept of quarantine changed, and it is applied to any period of time, not just to a forty-day period as it was originally in the Middle Ages. The word animales "animals" was added to the definition in the 1992 edition (DLE, 1992). It's remarkable that in the DLE 23.4 version the updated definition included things, which can also be put in quarantine as a preventive measure, which we all have learned perfectly during the pandemic.

Furthermore, the RAE dictionary includes three denominal synonymic verbs that have some slight differences. The verbs cuarentenar and cuarentenear are very similar, but the former is normally used as a transitive or a pronominal verb (cuarentenarse) and rarely as an intransitive one. And vice versa: the latter is intransitive and may rarely be used as a transitive verb. The verbal inflection -ear is quite productive, and it seems that the verb cuarentenear "to spend the quarantine" was formed by analogy with such verb as veranear "to spend the summer".

\section{cuarentenar}

tr. 1. Poner algo o a alguien en cuarentena (\| aislamiento preventivo por razones sanitarias). Cuarentenaron un hospital. U. t. c. prnl. Se cuarentenó durante la epidemia. - "To put someone or something in quarantine (\| a preventive isolation for health reasons). A hospital was quarantined. Also used as pronominal. He/she quarantined himself/herself during the epidemic". intr. 2. p. us. Pasar un período de cuarentena (\| aislamiento preventivo por razones sanitarias). Se permite el regreso a la ciudad de origen para cuarentenar. - "rare. To spend a period of quarantine (\| a preventive isolation for health reasons). Return to the city of origin for quarantine is allowed.

\section{cuarentenear}

intr. 1. Pasar un período de cuarentena $(\|$ aislamiento preventivo por razones sanitarias). Es más llevader o cuarentenear con alguien. - "To spend a period of quarantine (\| a preventive isolation for health reasons). It's more bearable to spend the quarantine with someone". tr. 2. p. us. Poner algo o a alguien en cuarentena (\| aislamiento preventivo por razones sanitarias). Tendremos que cuarentenear el ganado. Las autoridades cuarentenearon el crucero. - "rare. To put someone or something in quarantine (\| a preventive isolation for health reasons). We will have to quarantine livestock. Authorities quarantined the cruise ship".

The transitive verb encuarentenar is formed by parasynthesis from cuarentena and corresponds to en- $\mathrm{N}-a r$, one of the most productive parasynthetic schemes (NGLE, 2009: 578).

\section{encuarentenar}

tr. Poner algo o a alguien en cuarentena (\| aislamiento preventivo por razones sanitarias). Si alguien se infecta, habrá que encuarentenar a toda la colonia. U. t. c. prnl. Me encuarentené por precaución. - "To put someone or something in quarantine (\| a preventive isolation for health reasons). If someone gets infected, the whole colony will have to be put in quarantine. Also used as pronominal. I put myself in quarantine as a precaution".

\section{Confinar word family}

There are five words belonging to the same family included in the DLE. In the case of the verb confinar, the participle confinado and the noun confinamiento some modifications were made.

\section{confinar}

tr. Encerrar o recluir algo o a alguien en un lugar determinado o dentro de unos límites. U. t. c. prnl. Se confinó EN su casa. - "To confine or enclose something or someone in a certain place or within certain limits. Also used as pronominal. He confined himself at home".

In the previous DLE edition (DLE, 2001) the definition was much more concise and more general: 'recluir dentro de límites' - "confine within limits". 
As far as the word confinamiento "confinement, lockdown" is concerned, two updates were made:

there was an amendment to the $1^{\text {st }}$ sense with the pronominal form confinarse "to confine oneself": m. 1. Acción y efecto de confinar o confinarse. - "Action and effect of confining or being confined".

- a new meaning was added: m. 2. Aislamiento temporal y generalmente impuesto de una población, una persona o un grupo por razones de salud o de seguridad. El Gobierno decretó un confinamiento de un mes. "Temporary and usually imposed isolation of a population, a person or a group for health or safety reasons. The government decreed a one-month lockdown."

Originally, the word confinamiento was a judicial term meaning 'a sentence whereby the convicted person is obliged to live temporarily, in freedom, in a place other than his or her home' (DLE), the definition that passed from the second to the third place in the updated version entry: 3. m. Der. Pena por la que se obliga al condenado a vivir temporalmente, en libertad, en un lugar distinto al de su domicilio.

In the case of confinado "confined", a new meaning was added, and modifications were made to the two definitions of the previous DLE version (DLE, 2001).

\section{confinado, da}

Modified definition: adj. 1. Dicho de una persona: Obligada a vivir en un determinado lugar. U. t. c. s. - "Said of a person: Obliged to live in a certain place. Also used as a noun".

Compare with: Dicho de una persona: Condenada a vivir en una residencia obligatoria. U. t. c. s. (DLE, 2001). - "Said of a person: Sentenced to live in a compulsory residential home. Also used as a noun".

New meaning: m. y f. 2. Persona sometida a un confinamiento (\| aislamiento impuesto a una población). - "Person under lockdown (\| imposed isolation of a population)".

Modified definition: 3. Der. En algunos países, persona que sufre la pena de confinamiento. - "Law. In some countries, a person suffering the penalty of confinement".

Compare with: 2. m. Der. Hombre que sufre la pena de confinamiento (DLE, 2001). "Law. A man suffering the penalty of confinement".

New entries were also added for the verb desconfinar and the noun desconfinamiento formed with the help of the prefix des- which denotes reversal of the meaning of their lexical bases (confinar and confinamiento) but only in reference to the lockdown:

\section{desconfinar}

tr. Levantar las medidas de confinamiento impuestas a una población, o a parte de ella, en un territorio u otro lugar. U. t. c. intr. y c. prnl. - "To lift the measures of lockdown imposed on a population, or part of a population, in a territory or other place. Also used as intransitive and pronominal".

\section{desconfinamiento}

m. Levantamiento de las medidas impuestas en un confinamiento. - "Lifting of the measures imposed during lockdown".

\section{Other new entries}

desescalada "de-escalation"

f. 1. Descenso o disminución graduales en la extensión, intensidad o magnitud de una situación crítica, o de las medidas para combatirla. - "Gradual decrease or decline in the extent, intensity or magnitude of a critical situation, or in the measures to combat 
it”. 2. Reducción progresiva de las operaciones militares en un conflicto bélico. "Phasing out military operations in a war conflict".

The word desescalada, which seems to be a calque of the English deescalation, was frequently used in reference to the period of gradual decrease in the measures to combat the COVID-19 pandemic last summer, for example:

"El Gobierno ha establecido una desescalada en España que se distribuye en cuatro fases antes de llegar a la conocida como "nueva normalidad"” (https://www.elmundo.es/espana/2020/06/01/5ed4c57efdddff2e0c8b4623.html)

"The government has implemented a de-escalation in Spain that is divided into four phases before reaching what is known as the "new normal"".

It is striking that it was registered by the RAE only last year. The word was documented in the Diccionario del español actual as 'disminución en la extensión, intensidad o magnitud [de algo, esp. de la lucha o la violencia]' "decrease in extent, intensity or magnitude [of something, especially of the struggle or violence]" in 1999 with examples taken from newspapers published in 1969 and 1970 (DEA I, 1999: 1516). So, the word itself is very old.

Its antonym and lexical base escalada appeared for the first time with the meaning 'aumento rápido y por lo general alarmante de alguna cosa, como precios, actos delictivos, gastos, armamentos, etcétera' "rapid and usually alarming increase in something, such as prices, criminal acts, expenditure, armaments, etc." in the Spanish Royal Academy dictionary in 1984 (DLE, 1984: 575). At the present moment it is frequently employed in reference to the inverted process of de-escalation, i.e., the increase of restrictive measures and aggravation of the health situation: "Escalada de restricciones al llegar a un nuevo máximo de muertes en la segunda ola" (https://www.efe.com/efe/espana/sociedad/escalada-de-restricciones-al-llegar-a-unnuevo-maximo-muertes-en-la-segunda-ola/10004-4387162). _ "Escalation of restrictions as second wave deaths reach a new peak".

The following two words have an indirect relation with the COVID-19 pandemic, as virtual communication substituted the real one and, in many occasions, became the only possible way of visual contact with other people during the lockdown:

\section{videochat}

m. Inform. Chat que incorpora funciones de video y audio. - "Chat that incorporates video and audio features"

videollamada "video call"

f. Comunicación simultánea a través de una red de telecomunicaciones entre dos o más personas, que pueden oírse y verse en la pantalla de un dispositivo electrónico, como un teléfono inteligente o una computadora. Pudieron conoceren seguida a su nieto gracias a una videollamada. - "Simultaneous communication over a telecommunications network between two or more people, who can hear and see each other on the screen of an electronic device, such as a smartphone or computer". They were able to meet their grandson immediately thanks to a video call.

\section{Other amendments \\ mascarilla "mask"}

f. Máscara que cubre la boca y la nariz de su portador para protegerlo de la inhalación y evitar la exhalación de posibles agentes patógenos, tóxicos o nocivos. Mascarilla quirúrgica, sanitaria - "Mask covering the wearer's mouth and nose to protect against inhalation and prevent exhalation of potential pathogens, toxic or harmful agents". Surgical, sanitary mask.

If we compare the recently updated definition with that of the previous edition (DLE, 2001), we'll see that the former is more technical and precise: 'máscara que cubre la boca y la nariz para proteger al que respira, o a quien está en su proximidad, de posibles agentes patógenos o tóxicos (DLE, 2001). - "Mask covering the mouth and nose to protect the wearer, or anyone in the vicinity, from possible 
pathogens or toxic agents". In addition to this, the amendment includes types of masks to illustrate the usage of the word mask.

\section{COVID-19 pandemic key words: productivity, analogy, and creativity}

\section{Confinamiento cluster}

In 2020 confinamiento was elected as the word of the year by FundéuRAE (Foundation of Urgent Spanish promoted by the Spanish Royal Academy) (https://www.fundeu.es/recomendacion/confinamiento-palabra-del-ano-2020-para-lafundeurae/), a fact which demonstrates the strength of the impact that it has had (and still has) on our lives. For example, from 1 January 2020 to 27 January 2021 the Google search engine gives us 14.200.000 results for this word only from Spanish websites.

If last year in Spain the term confinamiento implied people's isolation at their homes (as we can appreciate analyzing the Google search engine results, the compound term confinamiento domiciliario came into wide use in October of 2020 with the second pandemic wave: of 108 occurrences in Google only one occurrence dates from March 2020), nowadays it is necessary to specify the type of lockdown as it may be confinamiento domiciliario "domestic lockdown", confinamiento perimetral autonómico "autonomous perimeter lockdown", confinamiento perimetral provincial "provincial perimeter lockdown" or confinamiento perimetral municipal "local perimeter lockdown".

To designate a partial, non-domestic lockdown, one can use the prefixed form with the Latin compositional element semi- meaning 'almost', 'partially' semiconfinamiento:

"El Boletín Oficial de la Comunidad de Madrid ya recoge este viernes la orden mediante la que el Ministerio de Sanidad ha decretado el cierre de Madrid y otros nueve municipios [...]. El semiconfinamiento será efectivo desde este mismo viernes 2 de octubre a las 22:00 horas" (https://www.cope.es/actualidad/espana/noticias/hasta-cuando-durar-confinamientomadrid-20201002_925011). - "The Official Bulletin of the Community of Madrid has already published this Friday the order by which the Ministry of Health has decreed the closure of Madrid and nine other municipalities [...]. The semilockdown will be effective from Friday 2 October at 22:00 hours".

As the Spanish government doesn't declare a full domestic lockdown, other terms have been coined with quite a productive compositional element of Greek origin auto- 'self': the noun autoconfinamiento and the pronominal verb autoconfinarse to emphasise that home confinement can't be legally imposed at the present moment and should be voluntary:

"Varias Comunidades piden "autoconfinamiento" a sus habitants tras la negativa del Gobierno a un cierre completo" (https://www.20minutos.es/noticia/4543938/0/varias-comunidades-pidenautoconfinamiento-habitantes-negativa-gobierno-cierre-completo/). _ _ "Several Communities call for "self-lockdown" of their inhabitants after the government's refusal of complete closure".

"Ante la negativa del Ejecutivo de Pedro Sánchez, las Autonomías han llamado a sus habitantes aautoconfinarse" (https://www.20minutos.es/noticia/4543938/0/varias-comunidades-pidenautoconfinamiento-habitantes-negativa-gobierno-cierre-completo/). - "Faced with the refusal of Pedro Sánchez's government, the autonomous communities have called on their inhabitants to self-quarantine".

XLinguae, Volume 14 Issue 2, April 2021, ISSN 1337-8384, eISSN 2453-711X 
In the case of autoconfinamiento the use of auto- is justified but it is not so in the case of the pronominal verb autoconfinarse, as the particle -se already stands for 'oneself'.

From the basis of the noun confinamiento, two occasionalisms have been coined which are phonetically very close to the source word as they differ only in one letter, thus producing a humorous play on words.

\section{convinamiento} and confinamiento.

It is an overlapping blend of the prepositional phrases con vino "with wine"

Ana Isabel, (@anai_tic). «Convinamiento: dícese de las copas de vino que se toman para hacer más llevadera la cuarentena en casa».18 April 2020, 9:23 a. m. "Convinamiento: is said of glasses of wine drunk to make the quarantine at home more bearable. 18 April 2020, 9:23 a. m.

\section{confitamiento}

The word-play is based on the very close phonologic similarity of the verbs confinar and confitar "to candy". The occasionalism confitamiento may be considered as a deverbal noun derived from the verb confitar by analogy with confinar $\rightarrow$ confinamiento. Or it may be also considered a kind of overlapping blend.

Ángel, (@agpoycb). «Confitamiento: Adquisición de peso, producto de ingesta de bollería industrial, grasas saturadas y demás snacks salados durante el confinamiento». 4 de abril del 2020, 4:14 p. m. - Confitamiento: Weight gain from eating processed baked goods, saturated fats and other salty snacks during lockdown. 4 April 2020, 4:14 p. m.

\section{Coronavirus cluster}

The word coronavirus is a compound (corona + virus) that has developed a clipped form corona which, in turn, may be found in such compounds as coronabeso "coronakiss", coronabono "coronabond", coronabrazo "coronahug", coronabulo "coronahoax", coronaburro "coronaass", coronachiste "coronajoke", coronacoma, coronacompra "coronabuy", coronacrisis, coronacuento "coronatale", coronafake, coronajuego "coronaplay", coronaverso "coronaverse" (examples are taken from (Rodriguez-Ponga, 2020)). Here we may observe the development of the schema corona + noun which may become quite a productive one.

The occasionalism coronoia, which we find on Twitter, seems to be a case of contour blending (coronavirus+ paranoia) with the overlapping of $-n-$, by analogy with conspiranoia (conspiración + paranoia). With time -noia may be converted in a frequent splinter.

Bulnes, Ana (@mrs_jones). «Coronoia: eso que te entra cada vez que toses. Pulsión que hace que te pongas el termómetro varias veces al día». 15 de abril del 2020, 12:48 p. m. - "Coronoia: that thing you get every time you cough. An impulse to get the thermometer and take your temperature several times a day. 15 April 2020, 12:48 p. m.

\section{COVID cluster}

The name of the new disease has generated a lot of derivatives such as covidianidad, covidiano, covídico, covidoso, poscovid, pos-COVID, precovid, poscovídico (Rodriguez-Ponga, 2020) and the most famous telescoping blend covidiota,

In \#Covidcionario we find the following original occasionalisms:

Covidcoteca is an example of partial blending (covid + discoteca):

García-Salido, Alberto, (@Nopanaden). «Covidcoteca: apelativo para todo esos locales de ocio nocturno que no cumplen las recomendaciones para evitar el contagio de \#SARSCoV2. Pueden tener DJ, pero aunque sea residente no tiene ni idea de medicina». 2 de agosto del 2020, 10:29 p. m. - "Covidcoteca: this is the nickname 
for all those nightlife venues that do not comply with the recommendations to prevent the spread of\#SARSCoV2. They may have a DJ, but even if he is a resident, he has no idea about medicine". 2 August of 2020, 10:29 p. m.

In the last phrase, the author is also making a pun on the different meaning of the word residente: residente as a doctor who undertakes an internship in a hospital or health centre in order to obtain a specialist qualification in a branch of medicine and as a resident DJ (i.e., who is part of the club's staff).

Covierno is a contour blend (covid + Gobierno). It's important to note that at the phonological level, the difference is appreciated only in the first phoneme $(/ \mathrm{k} /$ vs. $/ \mathrm{g} /$ ), as in Spanish the letters $v$ and $b$ have the same pronunciation. The derogatory and critical attitude of the author to the government is quite evident.

Roman, Enrique, (@EnriqueRoman14). «Covierno: Gabinete de crisis(covid) que no vale para nada y solo mete la pata». 9 de abril del 2020, 6:58 p. m. "Covierno; Crisis (covid) cabinet that is good for nothing and only puts its foot in its mouth". 9 April of 2020, 6:58 p. m.

\section{Cuarentena cluster}

Besides the denominal verbs cuaretenar, cuarentear, encuarentar already registered in the DLE, we should mention several occasional blends. The most famous and ingenious blend in Spanish is cuarenpena (cuarentena + pena "sorrow") which is phonologically very close to the source word and which should be spelled as cuarempena according to the Spanish language spelling rules (https://www.fundeu.es/consulta/cuarenpena-cuarempena-cuarentena/).

Cuarentrena is an inclusive blend (cuarentena + entrena "train") as the second word is entirely included in the first.

Lasanta PT, Rubén, (@rubenlasantapt). «Cuarentrena: lo que está haciendo en su casa mucha gente que no hacía deporte desde Naranjito». 11 de abril del 2020, 1:39 a. m. "Cuarentrena: what a lot of people who haven't played sport since Naranjito [i.e., the mascot of the 1982 Football World Cup organised by Spain] are doing at home". 11 April of 2020, 1:39 a. m.

The occasionalism infinitena is formed by analogy with cuarentena from the adjective infinito "infinite" and the suffix -ena which is also found in such collective nouns as docena "dozen", quincena "fortnight". Its definition, in which the author expresses his or her despair, is as follows:

«Lo que originalmente decíamos que no era una cuarentena porque solo iba a durar quince días pero que ya van más de sesenta y no parece que vaya a acabar pronto» (https://covidcionario.com/infinitena/). - "What we originally said was not a quarantine because it was only going to last a fortnight but which has now lasted more than sixty days and does not seem to be ending any time soon".

\section{Pandemia cluster}

The adjective pandemial is coined after millennial and means 'of, relating to, or belonging to the COVID-19 generation', and as a noun, it may be defined as 'a person reaching young adulthood during COVID-19 pandemic':

«Generación Pandemial: cómo el coronavirus marcará para siempre el

futuro de tus hijos»
(https://www.elmundo.es/papel/futuro/2020/09/20/5f64d97efdddff9d848b45c9.html). - "Pandemial Generation: how the coronavirus will forever shape your children's future".

Plandemia is a result of a word-play based on the phonological similarity between pan and plan and, maybe, it is a calque of the English plandemic, occasionalism that came into use due to the conspiracy theory video titled "Plandemic: 
The Hidden Agenda Behind Covid-19". The following text explains very well the concept of plandemia:

"La aparición del nuevo coronavirus disparó en 2020 la desinformación en todas sus formas y alumbró una nueva gran teoría conspirativa, la "plandemia" -según la cual la pandemia fue planificada-, que se suma a otras que resurgieron con más fuerza: las que demonizan las vacunas o el 5G y el movimiento QAnon, que engloba a todas ellas" (https://www.efe.com/efe/espana/destacada/la-plandemia-gran-teoria-conspirativaque-broto-en-2020/10011-4433134). - "The appearance of the new coronavirus triggered disinformation in all its forms in 2020 and gave birth to a huge new conspiracy theory, the "plandemic" - according to which the pandemic was planned which joins others that resurfaced with more strength: those demonising vaccines or $5 \mathrm{G}$ and the QAnon movement, which encompasses all of them".

In the same text, we find another occasionalism derived from the noun plandemia: plandémicos "plandemic theory followers".

\section{Vacuna cluster}

The latest word creations are related with the COVID-19 vaccine as it is one of the most important topics at the present moment. I've found at least three new compound words.

Vacunódromo 'a spacious venue for mass vaccination' is a compound word (vacuna $+-d$ romo) formed with the help of the neoclassical combining form -dromo (Greek $\delta \rho o ́ \mu o \varsigma)$ “-drome”, which means 'course, race, place for running', by analogy with such words as hipódromo, aeródromo, autódromo, cosmódromo, rockódromo, velódromo or even botellódromo "bottledrome" 'binge drinking venue'.

"El Gobierno francés anunció este miércoles que apostará por abrir cientos de centros de vacunación, conocidos en este país como "vacunódromos", para acelerar el ritmo de inoculaciones contra el coronavirus" (https://www.20minutos.es/noticia/4533643/0/vacunodromos-vacunacion-masivafrancia/). - "The French government announced on Wednesday that it will open hundreds of vaccination centres, known in France as "vaccinodromes", to accelerate the pace of inoculations against the coronavirus".

Vacunómetro is another compound (vacuna + -metro) formed with the help of the neoclassical combining form -metro (Greek $\mu \varepsilon \dot{\tau} \tau \rho \nu$ ) "-meter" meaning 'measuring device', 'measure' by analogy via schema with alcoholimetro, calorímetro, cronómetro and many others.

"Pero desde el comienzo de la vacunación hemos visto que las comunidades autónomas han seguido ritmos desiguales en la administración de las dosis. Para hacer un seguimiento diario, en la Sexta Clave hemos creado el Vacunómetro, un 'ranking' en el que diariamente podrás comprobar el estado de la vacunación en España" (https://www.lasexta.com/programas/lasexta-clave/vacunometro-lasexta-claveconsulta-ritmo-vacunacion-cada-

comunidad_202101196006d4b722c7670001f8d3bd.html). - "However, since the beginning of vaccination we have seen that the autonomous communities have followed unequal rhythms in the administration of the doses. To monitor the situation on a daily basis, at the Sexta Clave we have created the Vaccinometer, a 'ranking' in which you can check the state of vaccination in Spain every day".

Scandals provoked by several cases of corruption in the sphere of vaccination have given birth to robavacunas "vaccine-stealer", a pejorative occasionalism coined by Inés Arrimadas, leader of the Spanish political party Cuidadanos. The exocentric noun robavacunas is composed by roba "steals" ( 3 rd person singular of the present indicative) and vacunas "vaccines", and corresponds to one of the most productive compositional schemes Verb + Noun, though the combination of these two words 
"La líder de Ciudadanos, Inés Arrimadas, ha asegurado este domingo en Barcelona que las dimisiones del Jemad y del consejero de salud de Murcia por saltarse la cola de las vacunas deben ser un ejemplo y no una anécdota, y ha pedido el compromiso ético del resto de formaciones para apartar de sus filas a todos los políticos "caraduras

'robavacunas'"'” (https://www.publico.es/videos/933674/arrimadas-dice-que-la-dimision-del-jemaddebe-ser-un-ejemplo-y-no-una-anecdota). - "The leader of Ciudadanos, Inés Arrimadas, has said this Sunday in Barcelona that the resignations of the Chief of the Defense Staff and the Health minister of Murcia for jumping the queue of vaccines should be an example and not an anecdote, and has called for the ethical commitment of the rest of the political groups to remove from their ranks all "vaccine-stealing scoundrel" politicians".

Robavacunas now has a synonym, i.e., the recently coined compound word vacunajeta (vacuna "vaccine" + jeta "cheek, imprudence"):

"Y con el inicio de la campaña de inmunización en España, han aparecido los 'vacunajetas': personas que, valiéndose de su posición, se han colado en la vacunación contra el Covid y han emprendido, antes de tiempo, su camino hacia la inmunidad" (https://heraldodeoregon.wordpress.com/2021/01/28/los-vacunajetas-lalista-negra-vacuna-coronavirus/comment-page-1/).

\section{"Pandemic" neology statistics}

My list of "pandemic" neologisms includes 93 words and, of course, is not exhausting. The calculations demonstrate that almost $81 \%$ of them are nouns. It's logical because nouns designate objects, phenomena, facts, existential entities, etc., i.e., the most significant categories for us. Some words may be used both as nouns or adjectives/participles (for example, pandemial or reclhuido).

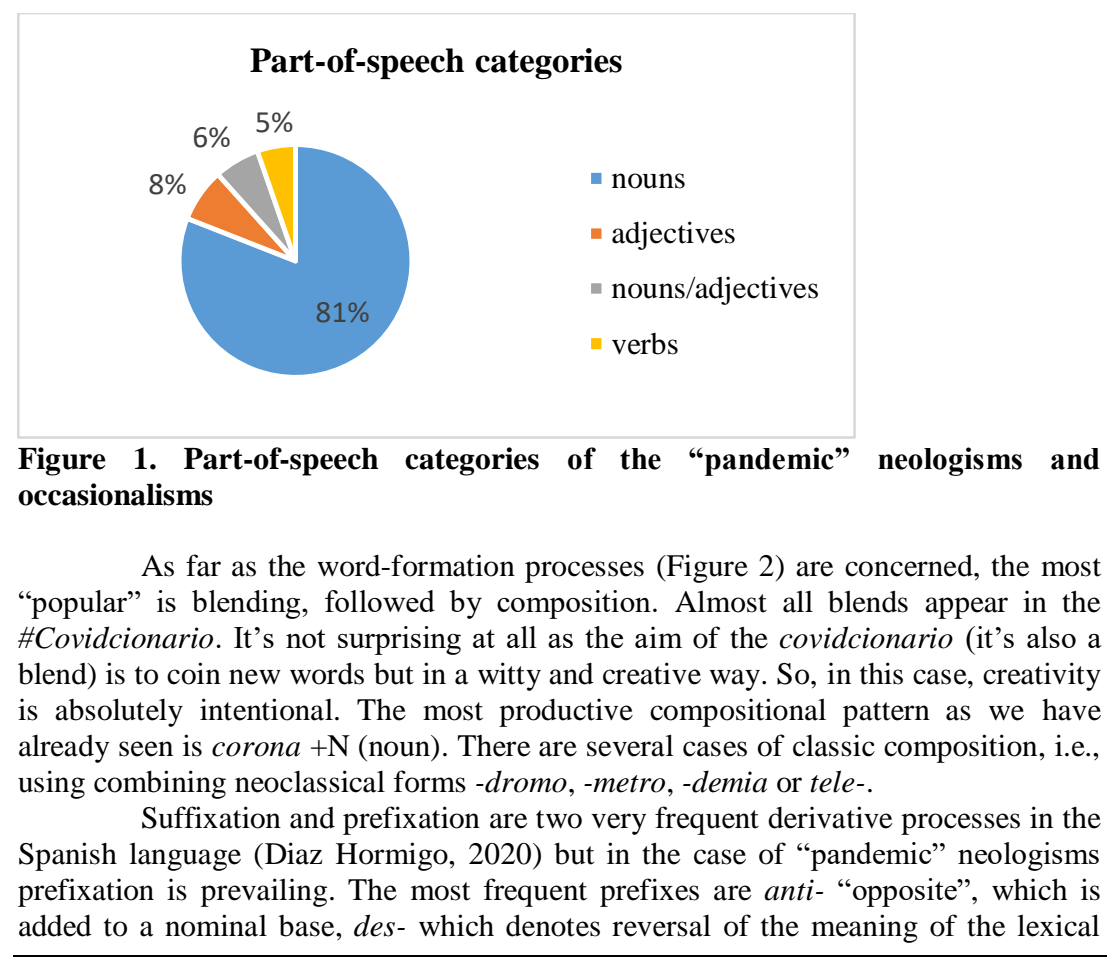

XLinguae, Volume 14 Issue 2, April 2021, ISSN 1337-8384, eISSN 2453-711X 
base, and the prefixes with temporal meaning pre- "before", pos- "after". Among the suffixes we find adjective suffixes (-al, -iano, -ico, -oso), verbal suffixes (-ar, -ear), and a nominal suffix -ismo which are added to nominal bases. The list also includes one case of clipping (corona), two acronyms (COVID, COVID-19), and one case of parasynthesis (encuarentar).

\section{Word-formation processes}

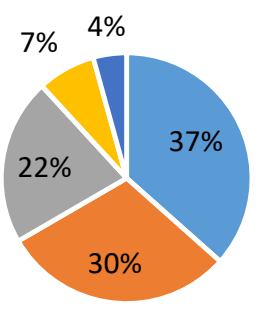

$$
\begin{aligned}
& \text { - blending } \\
& \text { - composition } \\
& \text { - prefixation } \\
& \text { - suffixation } \\
& \text { - other }
\end{aligned}
$$

Figure 2. Word-formation processes used in the coining of the "pandemic" new words

As we have seen, productivity and creativity are gradual concepts. In my sample list of "pandemic" new words, productivity as a rule-governed innovation doesn't play such a significant role as creativity (Figure 3). At one extreme of the scale productivity/creativity we find such examples as anticoronavirus, anticovid, encuarentear, coronavírico, desconfinar, desconfinamiento, autoconfinamiento, etc. which follow general, abstract word-formation rules, and, at the other extreme there are such occasionalisms as vacunajeta, resistireners, covierno, etc. which don't correspond to any word-formation rule. Of course, between these two extremes, there are intermediate cases which are coined by analogy with only one o very few lexemes (surface analogy), e.g., coronoia, infinitena, or by analogy via schema, e.g., coronacrisis, coronabonos, vacunómetro, vacunódromo, etc.

\section{Creativity vs. productivity}

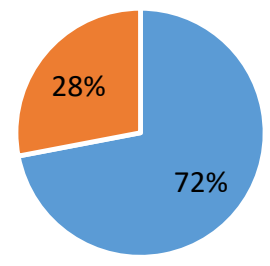

- creativity

- productivity

\section{Figure 3. Relation of the creative occasionalisms and the rule-based, predictable} formations

\section{Conclusion}

More than one year has passed since the unfortunate outbreak of the COVID-19 pandemic, which has affected and still is affecting absolutely every aspect of our life, and language is not an exception. The extraordinary impact on the Spanish language made the Spanish Royal Academy take a decision to include the most important, key "pandemic" words in the latest electronic dictionary version and 
amend some entries related with the pandemic the same year it began. Only a few of them might be considered neologisms (COVID, cuarentenar, cuarentenear, encuarentar, desconfinar, desconfinamiento). Other words were coined before the pandemic or even the last century (videochat, videollamada, seroprevalencia, coronavirus, coronavírico, desescalada) but became more "popular" and more widely used during the pandemic. Others developed new meanings during the pandemic and, thus, are semantic neologisms (confinamiento, confinar, confinado, desescalada) or just needed some refinements (mascarilla).

Lots of "pandemic" words have been left outside and wait their turn to be recorded in the language dictionary or to be forgotten like many other occasionalisms. The pandemic produced a wave of linguistic creativity never seen before. Sometimes it's a means of filling the existing lexical and conceptual gaps; sometimes it's a means of expressing strong criticism or humor through word-play to make the pandemic more bearable. The examples seen in this paper demonstrate once more that analogy is fundamental in word-formation. It's remarkable that the native speakers give preference to compound forms and blends, maybe, because it is the most laconic, expressive, and creative way of denoting complex phenomena that we are experiencing now. And we shouldn't forget the principle of hypostatization, term introduced by Lipka (1975: 200): "the mere existence of a name implies to a speaker that corresponding entity must exist in extralinguistic reality" (Honenhaus, 2007: 22).

It seems to me that this year the Spanish Royal Academy will have much more work to do, but I hope that one of the dictionary's new entries will be la era posCOVID or pospandemia.

\section{Bibliographic references}

ALVAR EZQUERRA, M. 2007. El neologismo español actual. In: Lexico español actual: Actas del I Congreso internacional de lexico español actual, Venecia-Treviso, 14-15 de marzo de 2005, pp. 11-36. ISBN 9788875431808.

BAUER, L. 1983. English Word-Formation. Cambridge: Cambridge University Press. ISBN 0521241677.

BAUER, L. - LIEBER, R. - PLAG I. 2013. The Oxford reference guide to English morphology. Oxford: Oxford University Press. ISBN 9780199579266.

CABRE, M. T. 1989. La neologia efímera. In: J. Massot (Coord.). Miscellania Joan Bastardas, 1 (Estudis de Llengua i Literatura Catalanes, XVIII), pp. 37-58. Barcelona: Publicacions de l'Abadia de Montserrat. ISBN 8478260692.

CABRE, M. T. 1993. La terminología. Teoria, metodologia y aplicaciones. Barcelona: Antartida/Empuries. ISBN: 8475964052.

CHIANG, W.-Y. - DUANN R. F. 2007. Conceptual metaphors for SARS: 'war' between whom? In: Discourse \& Society, vol. 18, n. 5, pp. 579-602. Available online: https://journals.sagepub.com/doi/pdf/10.1177/0957926507079631. ISSN (online) 1460-3624.

DA, 1737. REAL ACADEMIA ESPAÑOLA. Diccionario de la lengua castellana [...], tomo 5. Madrid: Imprenta de la Real Academia Española. No ISBN.

DEA I, 1999. SECO, M. RAMOS GONZALEZ, G., ANDRES O. Diccionario del español actual, vol. I. Madrid: Aguilar. ISBN 842945831X.

DIAZ HORMIGO, M. T. 2012. La formacion de palabras: tendencias predominantes en la derivación. In: E. Montoro del Arco (ed.). Neologia y creatividad linguistica. Valencia: Universitat de Valencia, pp.83-112. ISBN 9788437089799.

DIAZ HORMIGO, M. T. 2020. Neología y prensa escrita. Claves de unas interrelaciones necesarias. In: Tonos Digital, vol. 38, n. 2. Available online: http://www.tonosdigital.es/ojs/index.php/tonos/article/view/2399/1119. ISSN 15776921.

XLinguae, Volume 14 Issue 2, April 2021, ISSN 1337-8384, eISSN 2453-711X 
DLE, 1984. REAL ACADEMIA ESPAÑOLA. Diccionario de la lengua española. 20. ${ }^{\text {a }}$ ed. Madrid: Espasa Calpe. ISBN 8423947777.

DLE, 1992. REAL ACADEMIA ESPAÑOLA. Diccionario de la lengua española. 21. ${ }^{a}$ ed. Madrid: Espasa Calpe. ISBN 8423943992.

DLE, 2001. REAL ACADEMIA ESPAÑOLA. Diccionario de la lengua española. 22. ${ }^{\text {a }}$ ed. Madrid: Espasa Calpe. ISBN 8423968138.

DLE, 2014. REAL ACADEMIA ESPAÑOLA. Diccionario de la lengua española. 23. ${ }^{\text {a }}$ ed., [versión 23.4 en línea]. Available online: https://dle.rae.es

ESTORNELL PONS, M. 2013. Novedades y creacion lexica. In: Normas y usos en el español actual. Valencia: Tirant Humanidades. pp. 197-219. ISBN 9788415731429.

FLUSBERG, S. J.- MARLOCK, T. - THIBODEAU, P. H. 2018. War metaphors in public discourse. In: Metaphor and Symbol, vol. 33, n. 1, pp. 1-18. DOI: 10.1080/10926488.2018.1407992.ISSN 1092-6488 (Print), 1532-7868 (Online).

FUNDEU. Fundacion del español urgente. Avilable online: https://www.fundeu.es/ GUILBERT, L. 1975. La creativite lexicale. Paris: Larousse. ISBN 2030703400.

HADDAD HADDAD, A.- MONTERO-MARTINEZ, S. 2020. COVID-19: a metaphor-based neologism and its translation into Arabic. In: JCOM, vol. 19, n. 05, A01. DOI: 10.22323/2.19050201. ISSN 1824-2049.

HONENHAUS, P. 2007. How to do (even more) things with nonce words (other than naming). In: J. Munat (ed.). Lexical Creativity, Texts and Contexts. Amstredam/Philadelphia: John Benjamins Publishing Company, pp. 15-38. ISBN 978 9027215673.

KLEGR, A. - CERMAK, J. 2010. Neologisms of the 'On-the-pattern-of' Type: Analogy as a Word-formation Process? In: M. Prochazka, M. Mala, P. Sadova (eds.). The Prague School and Theories of Structure. Gottingen: V\&R unipress, pp. 229-244. ISBN 9783899717044.

LAKOFF, G. - JOHNSON, M. 1980. Metaphors we live by. Chicago, IL: University of Chicago Press. ISBN 0226468011.

LIPKA, L. 1975. Re-discovery procedures and the lexicon. In: Lingua, vol. 37, pp. 197-224.

LIPKA, L. 2007. Lexical creativity, textuality and problems of metalanguage. In: J. Munat (ed.). Lexical Creativity, Texts and Contexts. Amstredam/Philadelphia: John Benjamins Publishing Company, pp. 15-38. ISBN 9789027215673.

LLOPART-SAUMELL, E. 2019. Los neologismos desde una perspectiva funcional: Correlación entre percepción y datos empíricos. Revista Signos, vol. 52, n. 100. ISSN (Online) 0718-0934.

MATIELLO, E. 2017. Analogy in Word-Formation: A Study of English Neologisms and Occasionalisms. Berlin; Boston: De Gruyter Mouton. ISBN 3110548593.

MONTGOMERY, S. L. 1991. Codes and combat in biomedical discourse. In: Science as Culture, vol. 2(3), pp. 341-390. Print ISSN 0950-5431. On-line ISSN 1470-1189.

NAVARRO, F. A. 2020 La covid-19 y el lenguaje médico. In: Revista española de cardiología, vol. 73, n. 10, pp. 790-791. DOI: h10.1016/j.recesp.2020.06.021ISSN 0300-8932.

NGLE, 2009. REAL ACADEMIA ESPAÑOLA, ASOCIACION DE ACADEMIAS DE LA LENGUA ESPAÑOLA. Nueva gramatica de la lengua española, vol. 1. Madrid: Espasa. ISBN 9788467032451.

RODRIGUEZ-PONGA, R. 2020. El nacimiento de un nuevo vocabulario: consecuencias linguisticas de la pandemia. In: M. Kazmiercz, Signes M. T., C. Carreira Zafra (eds.) Pandemia y resiliencia: aportaciones academicas en tiempos de crisis, pp. 197-249. Navarra: EUNSA. ISBN 9788431335120

SALADRIGAS, M.V.- NAVARRO, F.A. - GOMEZ POLLEDO, P. - MUNOA, L. 2020. Glosario de covid-19 (EN-ES). Tremedica-Cosnautas. Available online: https://www.tremedica.org/tremediteca/glosarios/glosario-de-covid-19-en-es/. 
SONTAG, S. 1978. Illness as metaphor. New York: Farrar, Straus and Giroux. ISBN 9780374174439.

WALLIS, P. - NERLICH B. 2005. Disease metaphors in new epidemics: the UK media framing of the 2003 SARS epidemic. In: Social Science \& Medicine, vol. 60, pp. 2629-2639. DOI: 10.1016/j.socscimed.2004.11.031. ISSN 0277-9536.

Words: 8115

Characters: 54696 (18 standard pages)

Anna Zholobova

Department of Spanish Language

Facultad de Filosofía y Letras

Campus Universitario de Cartuja

18071 Granada

Spain

azholobova@ugr.es 


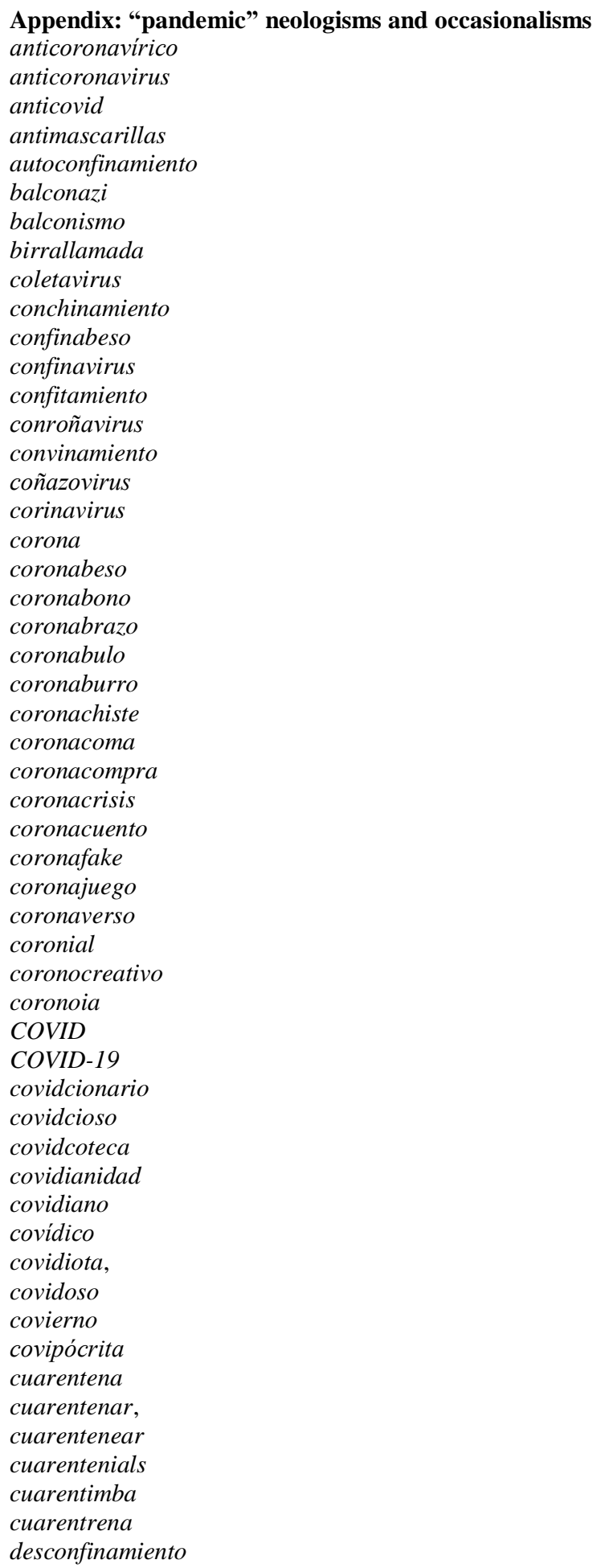




desconfinar
desescalabrada
desescalada
encuarentar
epimiedólogo
fandemia
inERTE
infinitena
infodemia
lecturentena
manguantes
manifectación
masbaratilla
pandemial
pandemiar
plandemia
plandémico
poscovid
pos-COVID
poscovidico
poscuarentena
pospandemia
precovid
prepandemia
presonas
psiCOVID19
reclhuido
resistireners
robavacunas
semiconfinamiento
seroprevalenta
sindemia
sinfinado
teledocencia
vacunajeta
vacunódromo
vacunómetro
videoyayadas
vinollamada
zoompleaños

XLinguae, Volume 14 Issue 2, April 2021, ISSN 1337-8384, eISSN 2453-711X 